\title{
DEVELOPMENT MODEL OF PROFESSIONAL COMPETENCE OF FUTURE PSYCHOLOGISTS
}

\section{МОДЕЛЬ РОЗВИТКУ ПРОФЕСІЙНОЇ КОМПЕТЕНТНОСТІ МАЙБУТНІХ ПСИХОЛОГІВ}

\section{Perogonchuk Natalia ${ }^{1}$}

DOI: http://dx.doi.org/10.30525/978-9934-571-27-5_39

Abstract. Dynamic and global changes, that covered all areas of social life, also caused significant changes in education. In order to correspond internally to modern reality, graduates of a higher education institution should not only adapt to the new situation, but also be able to change it and at the same time change and develop themselves. In these conditions, the most important task of higher education is a need to develop a model for the development of professional competence of future specialists.

Purpose: to prove the development model of professional competence of future psychologists in the context of modern society.

To create a model for the development of professional competence of future psychologists the ideas of scientific approaches such as systemic, personal-activity, personality-oriented, competence, synergistic, eco-facilitation, contextual were used. During the modeling the following principles of development of professional competence were used: the principle of systemic; the principle of humanity and the professional orientation of the model; the principle of model flexibility in conditions of variable educational space; the principle of model dynamism; the principle of variability of the model.

Internal psychological and external psychological and pedagogical conditions of development of professional competence of future psychologists are singled out. External conditions also include procedural and technological conditions: the presence of a scheme of an indicative basis of educational and professional activity in the form of a competence model of a specialist psychologist; purposeful development of all components of the professional competence of the future psychologist with the use of active

\footnotetext{
${ }^{1}$ Doctoral Student, Department of General and Social Psychology and Psychotherapy, National Pedagogical Dragomanov University, Ukraine
}

(C) Perogonchuk Natalia 
teaching methods, professional tests, reflection and reflexive self-diagnosis, portfolio method, etc.; systematic tracking (monitoring and self-analysis) of the development of professional competence of students during the entire period of study at the university. However, these external conditions are internalized into the internal conditions for the development of the professional competence of the future psychologist: the student's knowledge of the orientational basis of educational and professional activity in the form of a competence model of a specialist psychologist; the student has a sufficiently high level of development of polyfunctional competences - the professional orientation of the individual, the value-semantic sphere, which are the motivational basis of the educational, professional and future professional activity; the student has the necessary level of development of universal professional competences - emotional-volitional qualities (self-regulation) aspiration for changes, self-development, personal professional development plan, etc.

In its structure, professional competence is integrative, then for the componential division of the professional competence of future psychologists, an analysis of professional activity in the conditions of the university was carried out. As a result, the components of professional competence, that are formed in procedural dependence, such as: motivation and value; emotionally-volitional; cognitive; operational and activity; reflexive were determined.

Establishing the interrelations and the functioning of all components of professional competence is provided by psychological mechanisms, to which in our study we have included readiness for changes, self-regulation, self-organization, reflection, professional motives.

Structural components of the model reveal the internal organization of the process of developing the professional competence of future psychologists - approaches, principles, psychological mechanisms, psychological conditions, structural components and are responsible for the constant reproduction of interaction between the elements of this process.

\section{1. Вступ}

На сучасному етапі розвитку суспільства у контексті євроінтеграції, модернізації освітньої галузі з урахуванням вимог Болонського процесу, актуалізується проблема розвитку професійної компетентності майбутнього фахівця. Зафіксувати конкретний зміст знань, який треба передати під час професійної підготовки майбутніх психологів 


\section{Development model of professional competence of future psychologists}

можливо, проте в змінних умовах суспільства виникають все нові і нові професійні ситуації, які потребують постійного вдосконалення власних знань або їх трансформації та сприяють розвитку особистості майбутнього фахівця. Професійна компетентність грунтується на знаннях і вміннях, але ними не вичерпується, обов'язково охоплюючи особистісне ставлення до них майбутніх психологів, а також його досвід, який дає змогу ці знання «вплести» в те, що вона вже знає студент та іiі спроможність збагнути життєву ситуацію, у якій вона зможе їх застосувати.

Розвиток професійної компетентності - це динамічний процес, який важко спрогнозувати, складно встановити чіткий взаємозв'язок між кваліфікацією спеціаліста і його успішністю, як і складно визначити саме поняття професійна компетентність, психологічні механізми та умови їі розвитку. Одним із шляхів вирішення цієї задачі є створення моделі розвитку професійної компетентності майбутніх психологів в умовах сучасного суспільства.

Мета: розробити та обгрунтувати модель розвитку професійної компетентності майбутніх психологів в умовах сучасного суспільства.

Поставлена мета реалізовувалася у вирішенні таких завдань:

1. На основі теоретичного аналізу визначити основні структурні компоненти розвитку професійної компетентності майбутніх психологів.

2. Обгрунтувати психолого-педагогічні умови розвитку професійної компетентності майбутнього психолога в сучасному освітньому просторі.

3. Розкрити психологічні механізми розвитку професійної компетентності майбутніх психологів та визначити їх роль та взаємозв’язок.

\section{2. Поняття модель: суть і характеристика}

Модель (лат. modulus - міра, аналог, зразок) у психології - це система об'єктів або знаків, яка відтворює істотні властивості системи-оригіналу; «узагальнений абстрактно-логічний образ конкретного феномену, який відображає і репрезентує суттєві структурні зв'язки предмету дослідження, представлений в наочній формі і здатний дати нове знання про об'єкт дослідження» [16].

Модель розвитку професійної компетентності, узагальнюючи проміжні моделі (моделі діяльності, моделі професійних характеристик, моделі розвитку), дозволяє спрогнозувати розвиток тих 
характеристик майбутнього фахівця, на основі яких можна зробити висновок про сформованість професійної компетентності, в контексті дослідження.

На думку В.І. Загвязинский [3], модель буває: описовою (це текст, що розкриває принципи освіти, його етапи та технології, зв'язку між проблемою, змістом, способами його трансформації і результатами); структурної (представляє ієрархію компонентів системи); функціональної або функціонально-динамічної (модель із застосуванням схем і порівняльних таблиць, які розкривають зв'язки між елементами і способами функціонування системи).

У процесі побудови моделі розвитку професійної компетентності психолога, ми, опиралися на концепції професійного розвитку, представленої в роботах Н.Н. Нечаева [9]. 3 точки зору автора, в процесі професійного становлення майбутніх психологів можна виділити три базових рівня - предметний, теоретичний та практичний. Предметний рівень передбачає формування професійних установок, уявлень, концепцій, що визначають професійне сприйняття та інтерпретацію реальності. Цей рівень професійної діяльності в цілому співпадає 3 початковою стадією вузівської підготовки. Автор розглядає його як базу для створення професійно значимих характеристик професійної діяльності. Другий рівень професійного розвитку - це теоретичний. Він включає в себе засвоєння цілого спектру теоретичних концепцій та підходів вітчизняної та зарубіжної психології. Даний рівень відображає результати формування основних структур професійного мислення, зокрема, спеціалізованого внутрішнього плану дій, адекватних форм і методів професійної діяльності.

Практична стадія професійної розвитку в університеті передбачає формування здатності самостійно ставити задачі та вирішувати їх. Це останній етап у професійному розвитку особистості студента в виші, як правило, цей етап редукований, хоча, згідно Н.Н. Нечаєву, він $є$ найбільш значимим у підготовці майбутнього психолога [9].

Структурно-функціональна модель розвитку професійної компетентності у майбутніх психологів характеризується цілісністю, взаємодією структурних компонентів, умов їх функціонування і може виступати в ролі зразка/еталону в процесі професійної підготовки майбутнього психолога. Дана модель циклічна і передбачає освоєння всіх рівнів на кожному етапі професійного становлення майбутніх психологів. 


\section{Development model of professional competence of future psychologists}

Для створення моделі розвитку професійної компетентності майбутніх психологів були застосовані ідеї - системного, особистісно-діяльнісного, особистісно-орієнтованого, компетентністного, синергетичного, екофасилітативного, контекстного підходів.

Вибір особистісно-діяльнісного підходу в якості практико-орієнтувальної тактики, при розробці моделі розвитку професійної компетентності, зумовлений обгрунтуванням умов для самоактуалізації майбутнім психологом у професійній діяльності та особистісного зростання, формування активності студентів за рахунок партнерських, довірливих суб'єкт-суб'єктних стосунків з викладачами, єдності зовнішніх і внутрішніх мотивів.

Згідно системного підходу професійна компетентність є підсистемою професійної підготовки майбутніх психологів, має відкритий вірогідний характер, володіє гнучкістю, динамічністю, а ефективність iii формування залежить від організації системних впливів у навчально-професійній діяльності.

Компетентнісний підхід пропонує принципове оновлення процесу вузівської підготовки на основі виокремлення професійних, ключових компетенцій, що забезпечать готовність до виконання професійних задач, до неперервності освіти і самоосвіти впродовж всього життя.

Особистісно-орієнтований підхід в освітній системі характеризується недирективним супроводом суб'єктів навчальної підготовки, підвищенні кваліфікації в процесі реалізації створюваних ними індивідуальних освітніх стратегій розвитку професійної компетентності. Чітке визначення і засвоєння професійних компетенцій виступає тільки як додатковий елемент у реалізації освітньої самоорганізації студента. Освітній продукт цієї особистісно орієнтованої підготовки виявляється полімодальним, гнучким, таким, що постійно розвивається. Врахування в навчальному процесі індивідуальних особливостей, інтересів та потреб майбутніх фахівців забезпечить розвиток індивідуальної саморегуляції, упевненість у своїх силах вирішувати проблемні навчально-професійні завдання [11].

Синергетичний підхід грунтується на домінуванні в процесі розвитку професійної компетентності майбутніх фахівців самоосвіти, самоорганізації і полягає в стимулюючому впливі на суб'єкта з метою його саморозкриття і самовдосконалення, самоактуалізації в процесі співпраці з іншими людьми і з самим собою. Синергетичний підхід 
використовується в психології при вивченні відкритих (обмінюються речовиною, енергією та інформацією), нелінійних (багатоваріантних і незворотних в плані розвитку), само розвиваючих (змінюються під впливом внутрішніх протиріч, факторів і умов) і само організованих (спонтанно упорядковуються, що переходять від хаосу до порядку) систем. Тому при виникненні проблемних ситуацій не має універсального варіанту, а головне завдання полягає в актуалізації зовнішніх i внутрішніх ресурсів майбутнього психолога для його конструктивного вирішення.

Екофасилітативний підхід, розроблений П. Лушиним, заснований на принципах гуманізму та екологічності (в профіцитарній логіці). Екофасилітація - це процес управління відкритою динамічною системою особистості з метою підтримання ії в стані самозміни та саморозвитку. Згідно даного підходу навчання допомагає моделювати спільне переживання навчальної ситуації, в якій викладач-професіонал виступає як посередник, який розширює професійні інформаційні горизонти і способи їх освоєння, сприяє фасилітативно супроводжує процес відповідно динаміці і характеру навчальної або особистісної саморегуляції в умовах утруднення, переходу, коли наявних засобів для оволодіння новим недостатньо [4].

Екофасилітативний підхід, розроблений П. Лушиним, заснований на принципах гуманізму та екологічності (в профіцитарній логіці). Екофасилітація - це процес управління відкритою динамічною системою особистості з метою підтримання ії в стані самозміни та саморозвитку. Згідно даного підходу навчання допомагає моделювати спільне переживання навчальної ситуації, в якій викладач-професіонал виступає як посередник, який розширює професійні інформаційні горизонти і способи їх освоєння, сприяє / фасилітативно супроводжує процес відповідно динаміці і характеру навчальної або особистісної саморегуляції в умовах утруднення, переходу, коли наявних засобів для оволодіння новим недостатньо [4].

Контекстний підхід характеризується активним навчанням iз застосуванням професійного контексту, що насичує навчальний процес елементами професійної діяльності. Відповідно до контекстного підходу, застосовуючи реальні професійні завдання з метою їх виконання, майбутні психологи стикаються з невизначеністю, коли певний час невідомі всі факти. За таких умов контекстний підхід виступає як 


\section{Development model of professional competence of future psychologists}

передумова та рушій розвитку професійної компетентності майбутніх психологів [1;2].

В ході моделювання використовуються запропоновані Н.Б. Пікантовою принципи процесу розвитку професійної компетентності: 1) принцип системності, що забезпечить цінність процесу розвитку професійної компетентності майбутнього психолога всіх його компонентів: цілей, змісту, методів, форм і результату даного процесу; 2) принцип гуманності і професійної спрямованості моделі, пропонуючи іiі оріснтацію на розвиток активної і творчої позиції студентів до майбутньої професійної діяльності на основі сучасних технологій як необхідної умови їх професійного зростання; 3) принцип гнучкості моделі в умовах змінного освітнього простору; 4) принцип динамічності моделі, які пропонують іiі розвиток, постійні зміни і наповнення новим змістом; 5) принцип варіативності моделі, що пропонує можливість науково розробляти і теоретично обгрунтовувати нові ідеї [13].

Розвиваючи ідеї Н.Б. Пікатової, вважаємо за необхідне доповнити принципом профіцитарності моделі - суть якого полягаю в упевненості викладача в тому, що студент володіє достатніми можливостями реагування на нову ситуації. Принцип самоорганізації соціальної освітньої екосистеми (передбачає прийняття того факту, що сучасний мінливий та невизначений стан освітнього простору створює оптимальне середовище для постійної зміни професійної компетентності майбутніх психологів [4].

Особливістю розробленої моделі розвитку професійної компетентності у майбутніх психологів є їі спрямованість на активізацію співпраці в навчально-професійній діяльності викладача і студента та визначається наступними властивостями: відкритістю, оскільки змістовне наповнення моделі залежить від впливу умов зовнішнього середовища (соціального запиту) і отримані результати роблять свій вплив на зовнішнє середовище; системністю, що обумовлено, перш за все, положеннями системного підходу до їі розробки і реалізації і тим, що процес розвитку професійної компетентності є підсистемою більш складної системи освітнього процесу; неадитивністю - функціонування моделі розвитку професійної компетентності у майбутніх психологів як системи не може бути зведене до суми функціонування окремих ії підсистем; рівневість, що передбачає сформованість різних рівнів професійної компетентності у майбутніх психологів і можли- 


\section{Perogonchuk Natalia}

вість переходу з одного рівня на інший; гнучкістю, яка проявляється в іiі мінливості з урахуванням соціального замовлення, варіативності у виборі організаційних форм і методів навчання; динамічністю, яка забезпечується її постійні зміни.

\section{3. Структурні компоненти розвитку професійної компетентності}

Сформовані наукові підходи в розробці моделі розвитку професійної компетентності майбутніх психологів, прагнучи до цілісності і системності розгляду певної моделі, не приділяють першочергової уваги аспекту розвитку особистості майбутнього психолога як найважливішої мети гуманістичної концепції сучасної освіти. Тому за основу побудови структури професійної компетентності майбутніх психологів була взята багатокомпонентна модель, що складається 3 структур професійної діяльності, особистісних якостей і індивідуальних властивостей.

У зв'язку з тим, що професійна компетентність у своїй структурі інтегративна, то для компонентного поділу професійної компетентності майбутніх психологів був проведений аналіз професійної діяльності в умовах вишу. В результаті визначилися доцільні складові професійної компетентності які формуються в процесуальній залежності, а саме: мотиваційно-ціннісний; емоційно-вольової; когнітивний; операційно-діяльнісний; рефлексивний.

Мотиваційно-ціннісний компонент, на нашу думку, характеризується наступними показниками: ставлення до професії як цінності; розуміння і переживання іiі значущості як для суспільства, так і для власного розвитку; інтерес до навчальних дисципліни і питань освіти в цілому; захопленість наукою і прагнення до самовдосконалення. Усвідомлення своїх потреб і можливостей, морально-етичних цінностей та співвіднесення їх із потребами, можливостями інших, а також порівняння їх із суспільними потребами та вимогами; здатність реально, без стійких упереджень та стереотипів сприймати внутрішній світ своїх клієнтів, вміти бачити в кожному позитивні якості особистості; усвідомлення та критичне осмислення своїх можливостей, здатність розуміти норми, культуру і цінності як соціальних груп, так і клієнтів; посадової ролі, особливостей впливу на клієнта, результативності власних бажань і переконань; готовність порівнювати себе $з$ іншими, змінюватися, духовно розвиватися разом зі своїми клієнтами. 


\section{Development model of professional competence of future psychologists}

Ціннісний компонент є основою позиції, яку суб'єкт визначає стосовно світу, суспільства, соціального оточення, самого себе та власної поведінки, це здатність брати на себе відповідальність, надавати підтримку іншим людям, будувати взаємодію на паритетній основі, виходячи 3 того, що цінності - це значення й ідеали, які визначають всі цільові установки соціальної поведінки особистості майбутнього психолога.

Емоційно-вольовий компонент - почуття, вольові процеси, що забезпечують успішний перебіг і результативність діяльності майбутнього психолога; емоційний тонус, емоційна сприйнятливість, цілеспрямованість, самовладання, наполегливість, ініціативність, рішучість, самостійність, самокритичність, самоконтроль.

Когнітивний компонент професійної компетентності, представлений сукупністю психологічних знань, забезпечує актуалізацію таких рефлексивно-когнітівних ресурсів саморозвитку, як самопізнання i самоаналіз, приводячи до підвищення рівня усвідомлення своїх особистісних і професійних якостей, формування цілісної професійної та особистісної «Я-концепції ». Когнітивний компонент професійної компетентності становить інструментальну основу для реалізації особистісно-професійного саморозвитку фахівців, пов'язаний з умінням грамотно застосовувати отримані психологічні знання при взаємодії 3 оточуючими людьми і здійснювати самовплив, що дає можливість майбутньому психологу використовувати накопичені практичні психологічні вміння і навички для розширення арсеналу наявних інструментальних ресурсів, що сприяють саморозвитку.

Операційний компонент професійної компетентності майбутніх психологів полягає в оволодінні професійними навичками та техніками, психологічним інструментарієм не тільки в семантичному, а й процедурному аспекті. Відбувається переорієнтація від розуміння до інтерпретації. У психології інтерпретація використовується у вузькому (прийом, комунікативна техніка, направлена на виявлення неусвідомлених фактів психічного життя, їх подальше осмислення у ході взаємодії психолога та клієнта, що потребує психологічної допомоги) та широкому смислах (характеристика процесу надання психологічної допомоги, що включає всі його етапи та забезпечує смислову гармонію індивідуального буття людини у світі).

Рефлексивний компонент виявляється в умінні свідомо контролювати результати власної діяльності, рівень особистого розвитку 
та особистих досягнень, сформованість таких якостей як креативність, ініціативність, здатність до самоаналізу та самовдосконалення. Рефлексивний компонент виступає як регулятор особистих досягнень, рушій пошуку особистісного змісту у спілкуванні з людьми, самокерованості, формування індивідуального стилю діяльності у майбутній професійній діяльності.

3 огляду на те, що мотиваційно-ціннісний і емоційно-вольової етапи виконують функцію «пускового механізму» розвитку професійної компетентності майбутнього психолога, когнітивний і операційно-діяльнісний - створюють інформаційний і практико-орієнтований плацдарм, рефлексивний - дозволяє визначити рівневі показники компонентного складу професійної компетентності.

\section{4. Психологічні умови розвитку \\ професійної компетентності майбутніх психологів}

Розвитку професійної компетентності у майбутніх психологів сприяють психолого-педагогічні умови. Серед умов, що обумовлюють розвиток професійної компетентності, ми виділяємо внутрішні умови, що забезпечують здатність застосовувати отримані знання і досвід у професійній діяльності (інтелектуальні здібності, креативність, особистісні властивості і індивідуально-типологічні особливості), готовність до виконання професійної діяльності, що має на увазі рівень сформованості професійної позиції; і зовнішні умови, які передбачають ресурс навчального закладу (навчальні досягнення студентів, якість освітнього процесу) і включення особистого досвіду майбутніх психологів в с освітню організацію.

До групи зовнішніх належать умови, в яких здійснюється професійна діяльність майбутнього психолога.

На думку Л.М. Мітіної як чинник, що впливає на розвиток професійної компетентності, слід розглядати професійну освіту та освітній простір підготовки майбутнього фахівця [6].

Психологічні умови розвитку професійної компетентності майбутнього психолога розкривають якісну характеристику основних факторів освітнього простору і відображають головні вимоги до організації його сукупних можливостей, так Перегончук Н.В. виокремлює такі: освітній простір є не тільки джерелом інформації, а можливістю для саморозвитку майбутнього фахівця; актуалізує потребу для постійного 


\section{Development model of professional competence of future psychologists}

оновлення знань (неперервна освіта, освіта продовж всього життя і у різних інституціях - формальна, неформальна, інформальна); особистісно усвідомленим (мотиви, цінності, орієнтації, потреби) та особистісно зоріснтованим (професійний та особистісний розвиток, оптимізація особистісного потенціалу); актуалізує активність майбутнього психолога; розширює межі навчального діалогу, що сприяє розвитку професійно важливих якостей майбутнього психолога (рефлексія, самопізнання, самоконструювання) [12].

Другою психолого-педагогічною умовою розвитку професійної компетентності майбутнього психолога виступає особистість самого викладача. На думку М.К. Мамардашвілі [5] спеціально підготувати майбутнього фахівця будь-якої професії, неможливо, адже, найкраща передача знань відбувається тоді, коли педагог не займається педагогікою, сам спеціально не вчить, а є прикладом проживання свого життя як професіонала. Навчання допомагає моделювати спільне переживання навчальної ситуації, в якій викладач-професіонал виступає як посередник, який розширює професійні інформаційні горизонти i способи їх освоєння [4]. Найсуттєвішим моментом тут є не стільки знання, вміння і навички, отримані під час взаємодії викладач-студент, а зміна і структурування внутрішнього простору майбутнього фахівця, демонстрація способів самопізнання, самоконструювання, рефлексії, екзистенційного саморозуміння і т.п. Викладач-психолог виступає як безпосередній стимул нового смислу освоюваних в навчанні знань, умінь і навичок, форм організації поведінки, життя в цілому.

Безпосереднє спілкування 3 професіоналом створює умови для здійснення переходу майбутнього психолога через кордон власного розуміння в світ професійної свідомості і професійної семантики. I тільки так з поля допрофесійної функціонування суб'єкт назавжди переміщується в поле професійного функціонування [10].

Третьою психолого-педагогічною умовою розвитку професійної компетентності майбутніх психологів $\epsilon$ неперервність та різноманітність (формально, неформальна та інформальна) освіти.

На думку Т.В. Мухлаевої [8] розвиток потенціалу неформальної освіти здатне найбільш повно реалізувати ідею освіти протягом всього життя. Це дозволяє виділяти цілий ряд специфічних характеристик неформальної освіти, безумовно затребуваних в сучасному суспільстві: орієнтація на конкретні освітні запити різних груп населення; 


\section{Perogonchuk Natalia}

особлива увага до освітніх потреб конкретних категорій людей; високий рівень персональної активності студентів, заснованій на власній мотивації; внутрішня відповідальність студентів за результат освітньої діяльності, високий особистісний смисл навчання; розвиток професійної мобільності в швидко змінних умовах сучасного світу; розвиток професійно важливих якостей особистості, що забезпечують сприятливі передумови для професійної діяльності та гідного життя загалом; організація стосунків між учасниками освітнього процесу на взаємній повазі, демократичній культурі.

Інформальна освіта - індивідуальна пізнавальна діяльність, що супроводжує повсякденне життя і необов'язково носить цілеспрямований характер; спонтанна освіта, що реалізується за рахунок власної активності індивідів в насиченому культурно-освітньому середовищі; спілкування, читання книг, науково-популярної літератури, відвідування закладів культури, подорожі, засоби масової інформації; результати повсякденної робочої, сімейної чи будь-якої діяльності, що не має чіткої структури; спонтанно виникаючі можливості професійних ситуацій - спілкування з людьми психологічної професії. Всі ці, на перший погляд стихійні освітні агенти суспільства сприяють перетворенню їх освітнього потенціалу в діючі фактори розвитку професійної компетентності майбутніх психологів і їх особистості. Інформальна освіта пропонує створити умови для пошуку майбутнім фахівцем власної самоідентичності (прояв особистісного потенціалу, усвідомлення індивідом своєї суті, визначення свого місця в професійному середовищі і співвіднесення себе із фундаментальними цінностями). Інформальна освіта потребує не тільки реалізації освітньої діяльності через зовнішні впливи, але і обумовлює виникнення внутрішніх новоутворень, перетворень під впливом отримання нових знань [4; 12$]$.

Четвертою умовою розвитку професійної компетентності майбутнього психолога $є$ варіативність освітнього простору. Суть цієї умови можна описати у трьох вимірах: багатоманітність як кількісна характеристика, як якісна характеристика (несхожість, індивідуальність, «унікальність»); динамічність як процесуальна характеристика.

В контексті варіативності освітніх послуг можна говорити про їх адресність: здатність освіти відповідати мотивам і можливостям різних груп та їх індивідуальним можливостям; можливість управління змінами, інноваціями в одному освітньому просторі різноманітності. 


\section{Development model of professional competence of future psychologists}

Варіативним елементом змісту освіти виступають способи створення ситуацій, враховуючи суб'єктний досвід учасників і способи вирішення проблемних ситуацій. Основна функція запропонованого варіативного змісту освіти - надання освіті особистісного смислу, перехід освіти в самоосвіту. Для опису такого змісту освіти фіксуються границі «всередині» яких розгортається варіативний зміст і результат, до якого повинен прийти майбутній фахівець. Такими границями/еталонами в рамках компетентнісного підходу є компетенції, які можуть бути сформовані на будь-якому предметному змісті і практико-орієнтованій ситуації.

До зовнішніх умов також відносять - процесуально-технологічні умови: наявність схеми орієнтовної основи навчально-професійної діяльності у вигляді компетентнісної моделі фахівця-психолога; цілеспрямований розвиток усіх компонентів професійної компетентності майбутнього психолога з використанням методів активного навчання, професійних проб, рефлексії та рефлексивної самодіагностики, методу портфоліо та ін.; систематичне відстеження (моніторинг і самоаналіз) розвитку професійної компетентності студентів протягом всього періоду навчання у вузі. Проте, дані зовнішні умови ітеріоризуються у внутрішні умови розвитку професійної компетентності майбутнього психолога: володіння студентом орієнтовною основою навчально-професійної діяльності у вигляді компетентнісної моделі фахівця-психолога; наявність у студента досить високого рівня розвитку поліфункціональних компетенцій професійної спрямованості особистості, ціннісно-смислової сфери, які є мотиваційною основою навчально-професійної та майбутньої професійної діяльності; наявність у студента необхідного рівня розвитку універсальних професійних компетенцій - емоційно-вольових якостей, прагнення до саморозвитку, особистого професійного плану фахового зростання і т.п.

3 точки зору психології особливий інтерес представляють внутрішні умови, опосередковано або безпосередньо впливають на розвиток професійної компетентності майбутнього психолога відносять: самосвідомість, системне і творче мислення, мотиваційну сферу особистості. Знання і розуміння себе, можливість розкрити в собі потенціал, необхідний для самореалізації, пов'язані з розвиненою самосвідомістю; творче мислення, сприяє прийняттю нестандартних рішень в 
стандартних ситуаціях, допомагає побачити в загальновідомому нові грані. Системне ж мислення дозволяє підходити до проблеми глобально, оцінювати власну діяльність 3 точки зору її значущості для світового прогресу. Нарешті, прагнення реалізувати себе в професійній діяльності на основі розвиненої емоційно-вольової сфери формує професійні цілі, спрямованість особистості на досягнення успіхів при постійній роботі над собою. В якості основних внутрішніх чинників Л.М. Мітіна виокремлює мотиваційно-ціннісні орієнтації майбутнього психолога і очікування від самого себе як професіонала, що випливають 3 його майбутньої професійної діяльності, а також інтеріоризовані очікування і оціночні судження з боку безпосереднього його соціального оточення [6].

До групи внутрішніх факторів вчені [6] відносять: мотиви, захоплення, інтереси, які займають провідне місце в структурі особистості, пронизуючи спрямованість, характер, емоції, здібності, психічні процеси та ін.

Як одну із психологічних умов розвитку професійної компетентності майбутнього психолога Л.М. Мітіна виокремлює внутрішньоособистісні протиріччя як суб'єктивно пережита неузгодженість тих чи інших тенденцій у самосвідомості особистості, а основним засобом подолання внутрішньоособистісних протиріч вважає внутрішню активність особистості [6]. Грунтуючись на даному положенні вона розглядає внутрішню активність як внутрішній чинник, що впливає на розвиток професійної компетентності майбутніх психологів, їх самореалізації в професії, так і в напрямку самопізнання себе в майбутній професійній діяльності.

Розглянуті психолого-педагогічні умови сприяють успішному розвитку професійної компетентності майбутніх психологів, так як активізують навчально-пізнавальну діяльність, підвищує мотивацію до набуття нових знань, забезпечує послідовний перехід від засвоєння професійних знань до їх застосування, до самостійності у вирішенні професійних задач в умовах невизначеності освітнього простору та суспільства загалом.

Розвиток професійної компетентності майбутніх психологів - це перехід потенційних можливостей, накопичених майбутнім психологом в процесі вузівської підготовки в дієві (практико-орієнтовані), що відповідають специфіці його професійної діяльності. 


\section{Development model of professional competence of future psychologists}

\section{5. Психологічні механізми розвитку \\ професійної компетентності майбутніх психологів}

Визначення сутності поняття «психологічний механізм» розвитку професійної компетентності» базується на сукупності теоретичних положень. Ми виходили з того, що психологічний механізм як складно організоване внутрішне утворення цілісної структури розвитку професійної компетентності складає собою сукупність внутрішніх психічних перетворень, що виявляються в структурних змінах професійної компетентності, у взаємозв'язках його структурних компонентів; взаємодіючи 3 психологічними факторами і умовами, психологічними механізмами, що детермінують іiі розвиток.

До таких механізмів у нашому дослідженні ми включили такі: професійні мотиви, саморозвиток, саморегуляція, самоорганізація, рефлексія, готовність до змін.

Професійна мотивація - це процес наповнення смислами найбільш значимих стимулів праці, в результаті чого виникає структура у вигляді ієрархії смислоутворюючих мотивів, здатна здійснювати зворотній вплив на навчально-професійну діяльність особистості.

Саморозвиток майбутніх психологів - це цілеспрямований процес само- вдосконалення, детермінований метою і стратегією навчальної діяльності, здобуттям професійних знань, умінь та навичок, виникненням потреби розвитку професійних якостей. Потреба $є$ умовою активності майбутніх фахівців і визначає мотиви їхньої навчальної діяльності, пробуджує у них прагнення до професійного саморозвитку та самовдосконалення, бажання підвищити свої індивідуальні можливості, розвивати професійні якості [10].

Прагнення до безперервного саморозвитку визначається розвиненості самосвідомості, самоспостереження, самоосвіти, самоактуалізації (прагнення людини до можливо більш повного розкриття та розвитку своїх можливостей).

Саморегуляція-це «інтегративні психічні явища, процеси та стани», що забезпечують самоорганізація різних видів психічної активності» людини, «цілістність індивідуальності та становлення буття людини». Усвідомлена саморегуляція багаторівневий процес ініціації, побудови психічної активності та управління нею для досягнення усвідомлено висунутих і суб'єктних прийнятих цілей діяльності» [7, с. 8]. Саморегуляція розглядається як специфічна діяльність суб'єкта, що має 


\section{Perogonchuk Natalia}

індивідуальну структуру і стиль. Індивідуальний стиль визначається взаємодією різнорівневих механізмів, які реалізовують процес саморегуляції, тобто можна говорити про саморегуляцію як про систему психотехнологій, спрямованих на розвиток професійної компетентності майбутніх психологів. Високий рівень розвитку саморегуляції, який об'єктивно виражається в диференційованості і адекватності всіх усвідомлених інтелектуальних, емоційних, поведінкових реакцій, вчинків, вербальних проявів тощо, дає підставу стверджувати про наявність високого рівня розвитку професійної компетентності.

Самоорганізація - це механізм створення, відтворення, удосконалення організація складної динамічної системи. Процеси самоорганізації можуть мати місце лише в системах, що володіють високим рівнем складності і великою кількістю елементів, зв'язки яких мають не жорсткий, а імовірнісний характер [4].

Рефлексія - це механізм осмислення і переосмислення майбутнім психологом своєї професійної діяльності і себе як суб'єкта 3 метою прогнозування критичного аналізу, реорганізації, оцінки ефективності для розвитку особистості. Рефлексія - це професійна якість професіонала, що полягає передусім в обізнаності фахівця щодо процесів актуалізації особистості, реалізації рефлексивних здібностей в осмисленні й подоланні стереотипів мислення й утворення нового інноваційного змісту. Особливо велика роль рефлексії у переосмисленні особистісного та професійного досвіду, що сприяє формуванню нових професійних еталонів і стандартів, які стимулюють розвиток як особистість майбутнього фахівця так і професійну діяльність загалом. Це постійні роздуми про самого себе і свою діяльність [15].

Готовність до змін - готовність до зміни - це категорія суб'єктивної психологічної реальності, що являє собою активацію ресурсної, мотиваційної, енергетичної сфер психіки, не будучи безпосереднім механізмом поведінкових реакцій або продуктом вольових зусиль.

Д.В. Сапронов, Д.А. Леонтьєв, використовуючи поняття «прагнення до змін», «особистісний динамізм» описують їх через готовність до зміни при відсутності імперативної необхідності для цього [14]. Автори виокремлюють два рівня прояву змін - внутрішній і зовнішній. На внутрішньому, глибинному чи потенційному, зміни присутні у вигляді інтенційної передумови здійснення дій і вчинків, спрямованих на вільне усвідомлене здійснення своїх потенційних можливостей, 


\section{Development model of professional competence of future psychologists}

на розвиток себе як особистості. У внутрішньому плані прагнення до змін розгортається як процес активного порушення гомеостазу, породження внутрішньої перепони і іiі ж подолання. Зміни «потребують» від людини подальших дій і пов’язані з їх усвідомленням.

Таким чином, представлені психологічні механізми розвитку професійної компетентності, з одного боку підтримують ті знання, професійно важливих якостей, які вже є у майбутнього психолога, а 3 іншого сучасний мінливий світ змушує їх відповідати вимогам часу - актуалізувати ресурси зовнішнього і внутрішнього середовища майбутнього психолога для відповіді на виклики суспільства, професійної діяльності. Саме тому вагомого значення набувають такі психологічні механізми розвитку професійної компетентності як готовність до змін, саморозвиток, саморегуляція, рефлексія, самоорганізація, професійні мотиви.

\section{6. Висновки}

Розроблена нами структурно-функціональна модель розвитку професійної компетентності майбутніх психологів складає собою систему, що включає взаємопов'язані компоненти: мотиваційно-ціннісний; емоційно-вольової; когнітивний; операційно-діяльнісний; рефлексивний.

Встановлено, що змістом когнітивного компоненту є сукупність психологічних знань, необхідних для конструктивної професійної взаємодії; емоційного компоненту - позитивне ставлення до себе як до майбутнього професіонала; мотиваційно-ціннісного компоненту - прагнення до змін, сприяння власному особистісному та професійному зростанню; операційного компоненту - сукупність умінь і навичок, що забезпечують успіх професійної діяльності, подолання стереотипів на шляху негативного самосприйняття та сприйняття інших людей; рефлексивний - переосмислення власних дій та досвіду 3 метою подальшого самовдосконалення.

На розвиток професійної компетентності у майбутніх психологів впливають як внутрішні психологічні, так і зовнішні психолого-педагогічні умови. До внутрішніх умов належать: інтереси, внутрішня активність, здібності, мотиви і т.д. Зовнішні психолого-педагогічні умови забезпечують: методологічні принципи особистісно орієнтованої підготовки майбутніх психологів (самоорганізації соціальної освітньої екосистеми, екологічності освітнього простору, профіци- 


\section{Perogonchuk Natalia}

тарності, «компетентності самосупроводу»); системний, особистісно орієнтований, діяльнісний, екофасилітативний, контекстний методологічні підходи.

Структурні компоненти моделі розкривають внутрішню організацію процесу розвитку професійної компетентності майбутніх психологів - підходи, принципи, психологічні механізми, психологічні умови, структурні компоненти відповідають за постійне відтворення взаємодії між елементами даного процесу.

Перспективи подальших досліджень полягають у розробці форсайт-проекту розвитку професійної компетентності майбутніх психологів, враховуючи сучасні тренди в освіті та суспільстві.

\section{Список літератури:}

1. Вербицкий А.А. Активное обучение в высшей школе: контекстный поход / А.А. Вербицкий. - М. : Высш. шк, 1991. - 204 с.

2. Грицай Н. Сучасні підходи до методичної підготовки майбутніх учителів біології [електронний ресурс] / Н. Грицай. - Режим доступу: http://library.udpu.org.ua/library_files/probl_sych_vchutela/2013/visnuk_49.pdf

3. Загвязинский, В.И., Астаханов Р., Методология и методы психолого-педагогического исследования: учеб. пособие для студентов высш. пед. заведений / В. И. Загвязинский, Р. Астаханов - М.: «Академия», 2010. - 208 с.

4. Лушин П.В. Экологическая помощь личности в переходный период: экофасилитация: Монография / Лушин П.В. - Киев, 2013. - 296 с. - (Серия «Живая книга»; Т. 2).

5. Мамардашвили М.К.Какя понимаюфилософию/М.К. МамардашвилиМ.: Прогресс- Культура, 1992. - 416 с.

6. Митина Л.М. Психология развития конкурентноспособной личности / Л.М. Митина. - Воронеж: МОДЭК, 2002. - 400 с.

7. Моросанова В.И. Личностные аспекты саморегуляции произвольной активности человека / В.И. Моросанова // Психологический журнал. -2002. T. 23. № 6. C. 5-17.

8. Мухлаева Т.В. Международный опыт неформального образования / Т.В. Мухлаева // Человек и образование. - 2010. - № 4. - С. 158-162.

9. Нечаев Н.Н., Резницкая Г.И. Формирование коммуникативной компетенции как условие становления профессионального сознания специалиста / Н.Н. Нечаев, Г.И Резницкая // Вестник УРАО. - 2002. - № 1. - С. 3-21.

10. Онуфрієва Л.А. Дослідження психологічних детермінант розвитку професійної самосвідомості та особистісної зрілості майбутніх фахівців соціономічних професій / Л.А. Онуфрієва // Науковий вісник Миколаївського державного університету імені В. О. Сухомлинського. Сер. : Психологічні науки. - 2013. - Т. 2, Вип. 10. - С. 227-232.

11. Особистісно-орієнтована підготовка майбутніх психологів у системі післядипломної педагогічної освіти: посібник / П. В. Лушин, Н. Ю. Волянюк, 


\section{Development model of professional competence of future psychologists}

О. В. Брюховецька [та ін.] ; НАПН України, Ун-т менедж. освіти. - К., 2014. $222 \mathrm{c}$.

12. Перегончук Н.В. Формування професійної компетентності майбутніх психологів у сучасному освітньому просторі / Н.В. Перегончук // Наука і освіта. - № 11 - С. 49-55.

13. Пикатова Н.Б. Модель становления технологической компетентности у студентов педагогического колледжа / Н.Б. Пикатова // Вестник ЮжноУральского государственного университета. Сер. : Образование. Педагогические науки. - 2010. - № 23 (199). - С. 54-59.

14. Сапронов Д.В., Леонтьев Д.А. Личностный динамизм и его диагностика / Д.В. Сапронов, Д.А. Леонтьев // Психологическая диагностика. - 2007. № 1. - С. 66-84.

15. Степанов С.Ю., Семенов И.И., Новикова Е.Р. Типы и функции рефлексии в организации принятия решения оператора. - В кн.: Проблемы инженерной психологии. Вып. 2. Л., 1984. - С. 127-129.

16. Шапар В.Б. Сучасний тлумачний психологічний словник / В.Б. Шапар. Х.: Прапор, 2007. - 640 c.

\section{References:}

1. Verbitskiy A. A. (1991) Aktivnoe obuchenie v vysshey shkole: kontekstnyy podhod [Active learning in higher education: contextual approach]. Moscow: Vyssh. Shk. (in Russian)

2. Hrytsai N. Suchasni pidkhody do metodychnoi pidhotovky maibutnikh uchyteliv biolohii [Modern approaches to methodological training of future teachers of biology]. Retrieved from: http://library.udpu.org.ua/library_files/probl_sych vchutela/2013/visnuk 49.pdf (accessed 1 March 2018).

3. Zagvyazinskiy, V.I., Astakhanov R. (2010) Metodologiya i metody psikhologo-pedagogicheskogo issledovaniya: ucheb. posobie dlya studentov vyssh. ped. Zavedeniy [Methodology and methods of psychological and pedagogical research: Textbook. allowance for students of higher education. ped. establishments]. Moscow: Izdatel'skiy tsentr "Akademiya". (in Russian)

4. Lushin P.V. (2013) Ekologicheskaya pomoshch' lichnosti v perekhodnyy period: ekofasilitatsiya [Environmental assistance in the transition period: eco-facilitation] Kiev: Seriya "Zhivaya kniga”. (in Russian)

5. Mamardashvili M. K. (1992) Kak ya ponimayu filosofiyu [As I understand philosophy]. Moscow: Progress- Kul'tura. (in Russian)

6. Mitina L. M. (2002) Psikhologiya razvitiya konkurentnosposobnoy lichnosti [Psychology of development of a competitive personality]. Voronezh: MODEK. (in Russian)

7. Morosanova V.I. (2002) Lichnostnye aspekty samoregulyatsii proizvol'noy aktivnosti cheloveka [Personal aspects of self-regulation of voluntary human activity]. Psikhol. Zhurn, vol. 23, no. 6, pp. 5-17.

8. Mukhlaeva T.V. (2010) Mezhdunarodnyy opyt neformal'nogo obrazovaniya [International experience of non-formal education]. Chelovek i obrazovanie, no.4, pp.158-162. 


\section{Perogonchuk Natalia}

9. Nechaev N.N., Reznitskaya G.I. (2002) Formirovanie kommunikativnoy kompetentsii kak uslovie stanovleniya professional'nogo soznaniya spetsialista [Formation of communicative competence as a condition for the formation of professional consciousness of a specialist]. Vestnik URAO, no. 1, pp. 3-21.

10. Onufriieva L.A. (2013) Doslidzhennia psykholohichnykh determinant rozvytku profesiinoi samosvidomosti ta osobystisnoi zrilosti maibutnikh fakhivtsiv sotsionomichnykh profesii [Investigation of psychological determinants of professional self-awareness development and personal maturity of future specialists in sociological professions]. Psykholohichni nauky, vol. 10, no. 10 (91), pp. 227-232.

11. Lushyn P. V., Volianiuk N. Yu., Briukhovetska O. V. (2014) Osobystisnooriientovana pidhotovka maibutnikh psykholohiv u systemi pisliadyplomnoi pedahohichnoi osvity: posibnyk [Personality-oriented training of future psychologists in the system of postgraduate pedagogical education: the manual]. Kiev: NAPN Ukrainy, Un-t menedzh. osvity. (in Ukrainian)

12. Perehonchuk N.V. (2016) Formuvannia profesiinoi kompetentnosti maibutnikh psykholohiv u suchasnomu osvitnomu prostori [Formation of professional competence of future psychologists in modern educational space]. Nauka i osvita, no. 11, pp. 49-55.

13. Pikatova N.B. (2010) Model' stanovleniya tekhnologicheskoy kompetentnosti u studentov pedagogicheskogo kolledzha[Model of formation of technological competence among students of the Pedagogical College]. Vestnik YuzhnoUral'skogo gosudarstvennogo universiteta, no. 23 (199), pp. 54-59.

14. Sapronov D.V., Leont'ev D.A. (2007) Lichnostnyy dinamizm i ego diagnostika [Personal dynamism and its diagnostics]. Psikhologicheskaya diagnostika, no.1, pp. 66-84.

15. Stepanov S.Yu., Semenov I.I., Novikova E.R. (1984) Tipy i funktsii refleksii $v$ organizatsii prinyatiya resheniya operatora [Types and functions of reflection in the organization of decision-making by the operator]. Problemy inzhenernoy psikhologii [Problems of engineering psychology]. St. Petersburg, pp. 127-129.

16. Shapar V. B. (2014) Suchasnyi tlumachnyi psykholohichnyi slovnyk [Modern interpretive psychological dictionary]. Kharkiv: Prapor. (in Ukrainian) 